\title{
MUC-2-KLH Vaccine
}

National Cancer Institute

\section{Source}

National Cancer Institute. MUC-2-KLH Vaccine. NCI Thesaurus. Code C2465.

A peptide vaccine containing human mucin 2 (MUC2) protein conjugated with keyhole limpet hemocyanin (KLH), with potential antineoplastic activity. MUC2, a secretory or gel forming glycoprotein expressed predominantly in goblet cells of the gastrointestinal and respiratory tracts, is overexpressed as an aberrant or deglycosylated form in various tumors such as gastric carcinomas and some hormone-refractory prostate cancers. MUC2 protein is conjug ated with $\mathrm{KLH}$, an immunostimulant and a hapten carrier, to enhance immune recognition. Vaccination with MUC2-KLH may result in the production of antibodies as well as elicit a cytotoxic $T$ - lymphocyte $(C T L)$ response ag ainst tumor cells expressing MUC2. 